\title{
KANTISTA MONELTA KANTILTA
}

Immanuel Kantin filosofia. Toim. Vesa

Oittinen. Gaudeamus, 2013.

Vuonna 2009 Brian Leiter järjesti blogissaan hauskan äänestyksen. ${ }^{1}$ Likipitäen tuhat ääntä kerännyt vaalitulos vastasi seuraavaan kysymykseen: kuka on kaikkien aikojen "tärkein filosofi"? Ensimmäisen ja toisen sijan veivät varsin yllätyksettömästi Platon ja Aristoteles. Heti heidän jälkeensä Kant sai selvän kolmospaikan. Hume, Descartes ja Sokrates jäivät tylysti seuraaville sijoille.

Jotain Kantin - siis top 3 filosofin! - arvostuksesta kertoo, että nykyisin hänen filosofiaansa koskevia julkaisuja ilmestyy joinakin vuosina lähes tuhat kappaletta. Tarvetta Kantin filosofiaa yleisluontoisesti luotaavalle teokselle ei tarvitse sen kummemmin perustella, ainakaan filosofian historiasta kiinnostuneille.

Gaudeamuksen julkaisema Immanuel Kantin flosofia (2013) tarjoaa kattavan läpileikkauksen Kantin työstä. Vesa Oittisen toimittama teos sisältää johdanto-luvun lisäksi 17 artikkelia. Kirjoittajakaarti on koostettu sekä kotimaisista että kansainvälisistä Kantin filosofian tuntijoista.

Esitän, kommentoin ja osittain kritisoin seuraavassa tiiviisti teoksen artikkelien pääkohtia ja argumentteja. Aihepiirin laajuudesta johtuen en käsittele kaikkea.

"METAFYSIIKASTA MORAALIFILOSOFIAAN, ESTETIIKASTA POLITIIKAN TEORIAAN JA LOGIIKASTA USKONNONFILOSOFIAAN"

Yllä oleva alaotsikko on suora lainaus kirjan takakannesta. Lupauksensa mukaisesti Imma- nuel Kantin filosofia alkaa Kantin metafysiikan ja sen kritiikin pohjustuksella. Hartwig Frank aloittaa artikkelinsa huomauttamalla, että "Kantin mukaan ihmisellä on luontainen taipumus metafyysisiin spekulaatiohin ja järkevä tarve metafysiikkaan" (12). Napakka aloitus tekee heti selväksi, ettei Kant halunnut Pubtaan järjen kritiikissään tuhota tai täysin hylätä metafysiikkaa (yllättäen Hart (18) sivuhuomiona väittää Humen pyrkineen tähän, vaikka Treatisen ensimmäisen kirjan ja Enquiryn ensimmäisen luvun huolellinen ruotiminen osoittaa tämän käsityksen todella ongelmalliseksi). Perinteisen metafysiikan vika on sen uppoutumisessa ratkeamattomiin kiistoihin, joita puhdas järki yksin ei pysty ratkaisemaan. Jotta metafysiikka voisi tieteellistyä, tulee sen rajata tutkimusalueensa (laajassa mielessä ymmärretyn) tiedostuksen ennakkoehtojen tutkimiseksi. Metafysiikan kohtalonkysymys tiivistyy synteettis-apriorististen arvostelmien mahdollisuuteen. Näistä arvostelmista olisi ollut kiinnostavaa kuulla muutama esimerkki. Frank ei suoraan mainitse, millaisia synteettis- $a$ priorisia tietoväitteitä meillä Kantin mukaan on hallussamme. Artikkelin johtopäätös (22-23) ennakoi myöhempää Sami Pihlströmin artikkelia: Kant ei voi hyväksyä teoreettisessa mielessä yleistä metafysiikkaa eli ontologiaa, mutta esimerkiksi vapaus, Jumala ja sielun kuolemattomuus ovat käytännöllisen järjen moraalisina postulaatteina hyväksyttäviä.

Toni Kanniston laaja ja pikkutarkka artikkeli analyyttisen ja synteettisen erottelusta pyrkii selventämään sen merkityksen Kantin metafysiikalle. Kantin päämotivaatio oli asettaa kysymys synteettisen a priorin mahdollisuudesta. Erottelu siis sisälsi Kantille metafysiikkaa tukevan pyrkimyksen, toisin 
kuin 1900-luvun loogisessa positivismissa, jossa metafysiikan ilmaisut yritettiin osoittaa mielettömiksi. Artikkelin parhaana antina voi pitää analyyttinen-synteettinen ja a priori - a posteriori -jaottelujen erojen selvennystä. Edellinen on semanttinen, siinä missä jälkimmäinen on tieto-opillinen (34). Arvostelmien mieltäminen joko analyyttisiksi tai synteettisiksi on kontekstisidonnaista siinä mielessä, että arvostelmien erottelu on riippuvaista siitä, mitä käsitteistä ajatellaan. Näin erottelu ei ole ehdoton. Analyyttisten arvostelmien totuus määräytyy niistä koostuvien käsitteiden intensioiden nojalla, kun synteettisten arvostelmien todentaminen edellyttää käsitteiden ekstension, eli viittauksen kohteena olevat objektit. Kantin jako ei perustu logiikan ristiriidan periaatteeseen. Se ei myöskään koske kielen sanoja, kuten W. V. O. Quine Kantia kritisoidessaan 1950-1960-luvuilla oletti, vaan ajattelun käsitteitä (33). Kannisto käy artikkelinsa lopuksi läpi Quinen lisäksi Kripken ja Hintikan tulkintoja erottelusta ja toteaa niiden vastaavat puutteet ja myös ansiot (42-45). Hän tiivistää ongelman seuraavasti:

Metafysiikan arvostelmien on oltava yhtäältä $a$ priori, sillä niiden on esitettävä välttämättömiä totuuksia kaikesta mahdollisesta kokemuksesta; ja toisaalta niiden on oltava synteettisiä, koska ne koskevat maailmaa, eivät ajattelua tai maailmasta irrallisten käsitteiden välisiä suhteita. (41.)

Seuraavalla sivulla (42) mainitaan, että matematiikka ja puhdas luonnontiede ovat synteettis-apriorisia tieteitä. Esimerkkejä näiden tieteiden väitteistä ei mainita. Toiseksi itselleni jäi epäselväksi, miten nämä tieteenalat liittyvät Kantin metafysiikan "pelastusoperaatioon" ja tieteellistämiseen.

Markku Leppäkoski toteaa selventävässä artikkelissaan transsendentaalisen deduktion "olevan modernin filosofian eniten keskusteltu ja ehkäpä kaikista vaikein argumentti" (63). Sen tarkoituksena on tiettyjen puhtaiden $a$ priori käsitteiden oikeuttaminen. Deduktiolla ei tässä yhteydessä tarkoiteta ensisijaisesti matemaattis-loogista johtamista, kuten konkluusion välttämätöntä seuraamista premisseistä. Kant käyttää juridiikasta peräisin olevaa erottelua de facton ja de juren välillä. Näin käsitteiden oikeutus ei perustu pelkästään tiukkaan loogiseen päättelyyn. Pubtaan järjen kritiikin arvostelmien loogisten muotojen taulukko pohjustaa puhtaan ymmärryksen käsitteet. Jokainen arvostelma voidaan Kantin mukaan luokitella kvaliteetin, kvantiteetin, relaation ja modaliteetin suhteen. Leppäkoski pitää Kantin kuningasajatuksena, että "kaikki ykseys (yhdistäminen, kombinaatio) on ymmärryksen tuotetta". Aistimellisuus antaa moninaisuuden, jonka ymmärrys voi käsitteiden avulla yhdistää (69). Transsendentaalinen deduktio selventää Kantin transsendentaalisen idealismin projektia. Hänen mukaansa käsitteet ja kategoriat on välttämättä edellytettävä kokemuksen mahdollisuuden ehdoiksi. Ulkoiset objektit eivät ole olioita sinänsä, sillä tietomme objekteista edellyttää tietävän subjektin (74).

Pentti Määttänen pureutuu artikkelissaan käsitteiden ja objektien välisen suhteen klassiseen filosofiseen ongelmaan. Kantin filosofiassa ongelma koskee eritoten ymmärryksen käsitteiden ja havainnointien (Anschauungen) välistä juopaa: edelliset ovat intellektuaalisia ja jälkimmäiset aistimellisia, ja täten Kantin filosofiassa tyystin eri tekijöitä (78). Määttänen vetoaa skeemoihin näiden tekijöiden välittäjinä. Ne ratkaisevatkin mielenkiintoisella tavalla niin sanotun yksi-moni-ongelman, eli sen, miten esimerkikiksi yleinen kolmion käsite kattaa kaikki erilaiset kolmiot, kuten suora-, tasa- ja oikokulmaisen kolmion. Tässä tiedostuksen aktiivisen ja konstruktiivisen luonteen ymmärtäminen on tärkeää. Skeemat tarjoavat konstruoimisen säännöt ja menetelmät, joita yksittäisiin tapauksiin voidaan soveltaa. Skeemat ovat myös tärkeitä Kantin kopernikaanisen vallankumouksen ymmärtämiseksi. Määttänen kirjoittaa:"Luonto on kokemuksen kohteena puhtaan ymmärryksen ja 
järjen konstituoimisen tulos, ja se mahdollistaa myös puhtaan luonnontieteen eli objektiivisen tiedon hankkimisen luonnosta. Skeemoilla ja niiden analogioilla on keskeinen merkitys tämän jäsentymisen välikappaleina”. (86.) Tämä ratkaisu herättää kuitenkin seuraavan jännitteen. Kantin kopernikaaninen kumous asettaa ihmisen (subjektin, mielen, tiedostuksen ennakkoehdot) kaiken keskelle; miten siis Kantin teoria mahdollistaa "objektiivisen tiedon hankkimisen luonnosta"? "Luonnolla" tarkoitetaan yleensä jotakin ihmisisestä riippumatonta ja tämän olemassaoloa ajallisesti edeltävää. Tästä(näistä) "olio(i)sta sinänsä” ei voida tietää muuta kuin että se(ne) on(ovat) olemassa. Epäselväksi jää, miten Kantin transsendentaalinen idealismi voi oikeuttaa edellä mainitun objektiivisen tiedonhankinnan luonnontieteessä.

Ilmari Jauhiainen artikkeli "Kant ja fysiikka" on omaperäinen kirjoitus Kantin filosofian vähemmän tunnetusta puolesta. Esikriittisellä kaudella Newtonin fysiikka oli Kantille aito tieteen paradigma. Myös kriittisellä kaudellaan Kant pyrki teoksessaan Luonnontieteen metafyysiset alkuperusteet osoittamaan Newtonin aksiomaattisen järjestelmän luonnonlakien välttämättömyyden (110). Luonnontieteen mahdollisuus perustuu kausaaliseen maksiimiin ("kaikilla ilmenevillä tapahtumilla on oltava syy") ja siihen, etteivät kappaleet pysty itsenäisesti muuttamaan liiketilaansa (119-120). Tämä argumentti on hyvin linjassa Newtonin omien näkemyksien kanssa. Hieman outoa on, että Kant pitää Hirvosen tulkinnassa Newtonin ensimmäistä lakia luonnontieteen yleisimpänä lakina ja koko luonnontieteen mahdollisuusehtona. Eikö nimenomaan Newtonin toinen laki ole kaikkein yleisin kausaalisesti tulkittavissa oleva laki? Hirvosen artikkelin kiinnostavimpia kohtia on eittämättä foronomian (nykykielellä kinematiikan) ja dynamiikan jännitteiden suhde. Edellinen käsittää vain kappaleiden suhteelliset liikkeet, mutta jälkimmäisen on vedottava absoluuttiseen avaruuskoordinaatistoon kappaleiden suhteellisten ja todellisten liikkeiden erottamiseksi. Hirvosen johtopäätös tästä jännitteisestä suhteesta Kantilla onkin seuraava:"... lopullinen absoluuttinen avaruus jää kuitenkin aina saavuttamattomaksi ideaaliksi, joka tiedostuksemme on kuitenkin välttämättä oletettava liikekokemusten pohjaksi" (121). Kantin voi näin katsoa tarjonneen välittävän kannan Leibnizin relationismille, joka ei kyennyt selittämään suhteellisten ja todellisten liikkeiden välistä eroa, sekä Newtonin absolutismille, joka oletti eron selittäväksi tekijäksi absoluuttisen, havaitsemattoman avaruuden rakenteen.

Jussi Kotkavirta kirjoittaa perusteellisesti Kantin moraalifilosofiasta. Hän aloittaa historiallisella huomiolla, että Kantin ajatus täysiikäisistä, moraalisesti autonomisista toimijoista oli aikanaan varsin radikaali. Perinteisen luonnonoikeudellisen käsityksen mukaan vain pieni vähemmistö ihmisistä kykeni tiedostamaan sen jumalallisen lain, jonka seuraamista moraalinen toiminta edellyttäisi. Kantin uuden ajatustavan mukaan ihmiset kykenisivät itse säätämään järjen avulla itselleen yleispätevät moraalilait, joita kaikkien tulisi kunnioittaa ja jotka myös mahdollistaisivat onnellisuuden tavoittelun (164). Moraalisuus edellyttää ihmisen toiminnan vapauden, sillä ihmisellä tulee olla mahdollisuus"sitoutua siihen, miten asioiden tulisi olla", kuten Kotkavirta (174) kirjoittaa. Kant perustelee tämän transsendentaalisella idealismillaan, jossa luonnon kausaalisuus on ilmiömaailman osa, mutta ihminen on rationaalisena ja moraalisena olentona vapaa toimimaan. Ihmiseen voikin ottaa kaksi näkökulmaa, syiden ja seurausten sekä järkiperusteisten valintojen näkökulmat. Kategorinen imperatiivi tukeutuukin vahvasti järkeen: Kantin vakaumuksen"mukaan moraalisuus voi kiteytyä ainoastaan puhtaasti järkiperäisiin ja ehdottoman yleispäteviin periaatteisiin" (177). Tässä olisi ollut kiinnostavaa kuulla pohdintaa siitä, miten Kant perustelee ihmisen moraalisen motivaation. Ennen Kantin Tapojen metafysiikan perustusta brittisentimentalistit Hut- 
cheson, Hume ja Smith painottivat sympatian ja myötätunnon mekanismeja moraalisen toiminnan vaikuttimina, siinä missä Kant vetoaa hyvään tahtoon ja toiminnan velvollisuuden täyttämiseen.

Yksi teoksen ehdottomista helmistä on Pauline Kleingeldin artikkeli Kantin muuttuvasta rotukäsityksestä. Tyypillisesti johdantoluonteiset teokset eivät sisällä pohdintaa filosofian historian suurnimien mahdollisesta rasismista (tai myöskään seksismistä). Kleingeldin pääväite on, että vielä 1780-luvulla Kantin näkemykset olivat epäilemättä rasistisia, mutta tämä olennaisesti muutti käsityksiään 1790-luvun puoliväliin tultaessa. 1780-luvun alun antropologian ja maantieteen luennoilla Kant jakoi ihmiset neljään hierarkiseen rotuun: Amerikan alkuperäisasukkaat, neekerit $[s i c]$, hindut ja valkoinen rotu. Kant näki näiden "rotujen" välisiksi eroiksi etenkin autonomian ja kyvykkyyden tasot. Hän suhtautui hyväksyväksi kahden "alimman rodun" orjuuttamiseen (147). Näiden rasististen näkemysten voidaan katsoa olevan jännitteisessä suhteessa hänen Käytännöllisen järjen kritiikkinsä universalismin kanssa. Toisaalta Kantin kategorinen imperatiivi koskee persoonia, tai järjellisiä olentoja, ei biologista ryhmää, joten on myös mahdollista, että Kant 1780-luvulla kannatti johdonmukaista epätasa-arvoa. 1790-luvulla Kant muutti näkemyksiään radikaalisti, etenkin teoksissaan Ikuiseen raubaan ja Tapojen metafysiikka. Kosmopoliittisen oikeuden käsite turvasi nyt ei-valkoisille juridisen arvon (156). Kant tuomitsi eurooppalaisen imperialismin Afrikassa, Amerikassa ja Aasiassa, sillä valloittamisen "hallitsevat periaatteet ovat absoluuttisen vastakkaisia kosmopoliittiselle oikeudelle" (157), kuten Kant Ikuiseen rauhaan -teoksessaan kirjoitti. Kleingeld osoittaakin artikkelissaan, ettei Kantin rasismi ollut hänen ajattelunsa pysyvä piirre.

Kantin poliittisen filosofian kontekstissa keskeisenä tekijänä voidaan pitää Ranskan vallankumousta. Ranskassa alamaisten hallinta- vallalle antama mandaatti oli vajavainen, mikä johti epäluottamukseen sekä vallankumouksellisiin muutoksiin. Kant pyrki politiikan filosofiassaan löytämään valtiollista johtamistapaa, joka olisi muita mahdollisia vaihtoehtoja parempi (191). Rebecka Lettevall osoittaa artikkelissaan, että Kantin yhteiskuntafilosofia oli utooppista siinä mielessä, että se erotti toisistaan ihannevaltion sekä todellisen valtion. Historiallisen kehityksen myötä Kant ajatteli, että ihmisen on mahdollista saavuttaa ihmisen autonomiaa kunnioittava ihanneyhteiskunta, jossa hän seuraa järkeään ja on "luontoon sidottujen pyyteidensä yläpuolella"(193). Vaikka Kant painotti kansalaisten roolia lainsäätäjinä, hänen näkemyksensä ei nykyajan näkökulmasta ole kovin demokraattinen, sillä suurin osa aikusväestöstä (naiset ja suurin osa miehistä) on suljettu kansalaisuuden ulkopuolelle valtion suojajäseniksi (200). Lettevallin analyysi Kantin rauhanfilosofiasta on tavattoman mielenkiintoinen. Ikuiseen raubaan -teoksen ehdot rauhan saavuttamisesta ovat varsin moderneja: rauhantekoa ei voi hyväksyä sodan verukkeella, vakinaiset armeijat on pitkällä tähtäimellä lakkautettava, valtionvelan taso ei saa nousta liian korkeaksi ja kunniattomat sodankäynnin keinot, kuten salamurhaaminen ja myrkyttäminen, on kiellettävä. Ei olekaan yllättävää, että Kantin teos innoitti Kansainliiton perustamista ensimmäisen maailmansodan jälkeen. Toisaalta Kantin rauhanartikloiden kaikkein kiistanalaisin kohta on epäilemättä kielto puuttua toisten valtioiden asioihin. Hän ymmärsi valtiot oikeustoimijoiksi, joiden asioihin puuttuminen loukkaa niiden itsenäisiä oikeuksia. Silti valtioiden väliset sotilaalliset väliintulot voivat joskus olla oikeutettuja, kuten (ehkä) Jugoslaviassa 1990-luvulla tai Ruandassa 2000-luvulla (204-205).

Kantin kriittisen filosofian mukaan ihmisjärki ei kykene saavuttamaan a priori tietoa Jumalasta, sielun kuolemattomuudesta tai maailman perimmäisestä olemuksesta. Sami Pihlström pitääkin Kantia yhtenä länsimaisen filosofian historian vaikutusvaltai- 
simpana uskontokriitikkona (226). Samalla Kant oli luultavasti koko elämänsä vahvasti uskonnollinen ihminen ja katsoi, että esimerkiksi Jumalan olemassaololle on annettavissa eettis-metafyysisiä perusteita, "inhimillisesti jäsennettynä, moraalin kautta avautuvana", kuten Pihlström kiteyttää (227). Hän käy artikkelissaan ensiksi läpi Kantin Pubtaan järjen kritiikin rationalistisen teologian kritiikin koskien perinteisiä ontologisia, kosmologisia ja fysikaalisteologisia todistuksia. Tämän jälkeen hän siirtyy pohtimaan, miten Kantin tapauksessa esimerkiksi sielun kuolemattomuudelle ja minuuden pysyvyydelle "voidaan valita teoreettista järkeä perustavampi ja elämässämme merkittävämpi näkökulma, moraalin näkökulma" (239). Vastaavasti toisessa Kritiikissä Kant olettaa Jumalan korkeimman hyvän mahdollisuuden edellytyksenä, käytännöllisen järjen postulaattina (242-243). Vaikka edellisiä postulaatteja ei voi teoreettisesti todistaa, on meidän, pragmatistisen metafysiikan hengessä, lupa toivoa niitä.

Mari-Anne Virkkala pitää Kantin taidefilosofiaa koskevassa artikkelissaan keskeisenä jännitteenä säännön ja vapauden suhteita kaunotaiteen teoksissa (257). Estetiikassa arvostelukyvyllä on sekä määrittävä että reflektoiva tehtävä (258). Kant erottaa toisistaan makuarvostelmat, aistiarvostelmat ja tiedolliset arvostelmat. Kauneuden tavoittelussa ei tavoitella tietoa, joten mitään objekteja vastaavia käsitteitä ei tarvitse tietää (261). Kantin taideteorian voi Virkkalan mukaan kiteyttää pyrkimykseen noudattaa taiteen sääntöjä ja luomisen vapautta, joka on "kauneuden tuottaman mielihyvän peruslähtökohta" (277), mielikuvituksen ja ymmärryksen ollessa sopusoinnussa (263). Maun avulla taideteosta voidaan arvioida, mutta niiden luominen edellyttää Kantin mukaan elävöittävää periaatetta eli neroutta, kykyä, jolla voidaan "esittää esteettisiä ideoita" (267).
Harva tuskin jaksaa pohtia Immanuel Kantin filosofian jokaisen artikkelin kaikkia yksityiskohtia. Tämäkin kirja-arvio sivuaa vain noin kahta kolmasosaa koko teoksesta. Kaikenkattavuuden puutteesta teosta ei voikaan arvostella. Muutamissa kohdissa Kantin filosofiaa olisi voinut myös analysoida hieman kriittisemmin eikä tyytyä pelkkään suopeuden periaatteen avaamaan näkökulmaan. Esimerkiksi transsendentaalisella idealismilla ja velvollisuusetiikalla on filosofian perinteessä tunnettuja kilpailevia vaihtoehtoja, joiden esittämistä vasta-argumenteista olisi ollut mielenkiintoista kuulla lisää. Toisaalta esimerkiksi analyyttinen-synteettinen-jaottelua koskeva artikkeli, sekä Kantin rasismia ja poliittista filosofiaa käsittelevät artikkelit käyvät varsin kiitettävällä tavalla läpi Kantin filosofiaa kohtaan esitetyt kriittiset huomiot sekä mahdolliset vastaukset niihin.

Immanuel Kantin filosofia on suositeltava teos pitkäjänteiselle lukijalle, joka etsii mahdollisimman kattavaa ja vaativuustasoltaan johdantoluontoisen kokoomateoksen ylittävää Kant-kirjaa.

\section{- MATIAS SLAVOV}

VIITTEET

1. http://leiterreports.typepad.com/blog/2009/05/the20-most-important-philosophers-of-all-time.html 